\title{
Atrioventricular Septal Defect and Tetralogy of Fallot, a Single Tertiary Center Experience: A Retrospective Review
}

Khaled Alhawri ${ }^{*}$, Colin J McMahon, Mohammed Alrih, Yamin Alzein, Asad Khan, Suhaib Mohammed, Khaled Alalwi, Kevin Walsh, Damien Kenny, Jonathon McGuinness, Lars Nolke and Redmond JM

Department of Pediatric Cardiothoracic Surgery, Our Lady's Hospital for Sick Children, Crumlin, Dublin, Ireland

*Corresponding author: Khaled Alhawri, Department of Pediatric Cardiothoracic Surgery, Our Lady's Hospital for Sick Children, Crumlin, Dublin, Ireland, Tel: +966568994751; E-mail: alhawri@hotmail.com

Received Date: Aug 17, 2018; Accepted Date: Sep 24, 2018; Published Date: Oct 02, 2018

Copyright: $\odot 2018$ Alhawri K, et al. This is an open-access article distributed under the terms of the Creative Commons Attribution License, which permits unrestricted use, distribution, and reproduction in any medium, provided the original author and source are credited.

\begin{abstract}
Background: Complete atrioventricular septal defect in association of tetralogy of Fallot is a rare and complex disease that makes its repair more difficult than repair of either lesion alone. We reviewed retrospectively our experience in managing this lesion.

Methods: Between February 2006 and May 2017, 16 patients who underwent repair of CAVSD/TOF were reviewed retrospectively. Fifteen patients had trisomy 21. Five patients underwent primary repair, while eleven patients went for staged repair in the form of RVOT stenting $(n=9)$ or systemic to pulmonary (S-P) surgical shunt $(n=2)$. RVOT stenting has replaced surgical shunt since 2012 in our center. Early presentation with cyanosis was the main determinant factor for staged versus primary repair.

Results: The median age at first palliation was 46 days (range 15-99 days). The median age at total repair for both groups was 6 months (range 3-18 months), the median age for the palliated patients was 6.5 months (range 5-18 months) while the median age for primary repaired patients was 5 months (range 3-11 months). The median weight at final repair was $6.9 \mathrm{Kg}(3.7-8.2 \mathrm{Kg})$. The pulmonary valve was preserved in five patients $(31 \%)$, four of them had no prior palliation. Chylothorax occurred in $(50 \%)$. One late mortality occurred after final repair due to sepsis.
\end{abstract}

Conclusion: CAVSD/TOF can be repaired with low mortality and morbidity. The use of RVOT stent has replaced the surgical (S-P) shunt with acceptable results in our center.

Keywords: Atrioventricular septal defect; Tetralogy of Fallot; Right ventricular outflow tract stenting

Abbreviations AVVR: Atrioventricular Valve Regurgitation; BT: Blalock-Taussig; CAVSD: Complete Atrioventricular Septal Defect; ICU: Intensive Care Unit; LVOTO: Left Ventricular Outflow Tract Obstruction; PA: Pulmonary Artery; RVOTO: Right Ventricular Outflow Tract Obstruction; TAP: Transannular Patch; TOF: Tetralogy of Fallot; Vsd: Ventricular Septal Defect

\section{Background}

Complete atrioventricular septal defect (CAVSD) in combination with tetralogy of Fallot (TOF) is a relatively uncommon disease [1-3]. This congenital malformation have the combined features of CAVSD and TOF, specifically a non-restrictive inlet-type VSD, with anterior extension, ostium primum ASD, a common unpartitioned atrioventricular valve, antero-superior deviation of the infundibular septum and right ventricular outflow tract obstruction. This unique anatomic situation must be considered carefully when planning surgical correction.

Initial experiences with surgical correction were associated with high mortality $3.9 \%$ and $33 \%$ as reported in two different series [4]. However recent reports have demonstrated acceptable outcome [4,5]. Controversies exist in the approach of repair. Some believe that primary repair is considered superior to staged repair $[3,6]$ whilst others adopted staged repair in the form of right ventricular outflow stenting or systemic to pulmonary shunting followed by a final repair.

Many children with CAVSD/TOF have symptoms beyond the neonatal or even the infancy period. As in cases with TOF, the age at clinical presentation depends on the degree of right ventricular outflow tract obstruction. Such obstruction effectively serves as PA banding, protecting the pulmonary vasculature from the high pulmonary blood flow characteristic of CAVSD, thereby allowing repair at an older age. Severe cyanosis in the neonatal period indicates severe RVOTO.

We have adopted the use of right ventricular outflow tract stenting in patients with early presentation. In this study, we present our results in managing this complex disease.

\section{Patients and Methods}

Between February 2006 and May 2017, we retrospectively reviewed all patients who underwent CAVSD/TOF repair in Our Lady's Children's Hospital Crumlin Ireland. Patients data were collected from the patient charts, operative reports, intensive care computer based records, echocardiography reports, discharge reports and follow up reports. The ethical committee approved the study. 


\section{Surgical management}

Patients were managed conservatively unless they presented with severe cyanosis defined as less than $70 \%$ systemic saturation in our hospital protocol, where either a systemic to pulmonary shunt is constructed $(\mathrm{n}=2)$ or lately since 2012 a right ventricular outflow tract stent is inserted in the Cath lab ( $\mathrm{n}=9$ ). Hypothermic cardiopulmonary bypass was used in all cohort with the use of blood cardioplegia in all. All patients underwent two-patch technique to repair the CAVSD. The superior bridging leaflet was cut towards the annulus in seven patients (43\%). The repair of the right ventricular outflow tract was achieved by trans-annular patch in eleven patients. Monocusp was constructed in five patients. The Monocusp was constructed by autologous pericardium in two patients and by taking one leaflet with its sinus from the bovine jugular vein (Contegra ${ }^{\circ}$ ) conduit in three patients The ASD was closed by an autologous pericardial patch in all patients. Fenestration of the inter-atrial septum of 4-6 $\mathrm{mm}$ was created in all but one patient. The decision was based on surgeon preference. Conventional ultrafiltration CUF and modified ultrafiltration MUF was used at the end of all cases.

\section{Statistical analysis}

Patients' data were evaluated using numbers (percentage) for categorical variables and median (range) for continuous variables.

\section{Results}

A total of 16 patients underwent complete CAVSD/TOF repair. Thirty eight percent $(n=6)$ were males and $62 \%(n=10)$ were females. Fifteen patients (94\%) have trisomy 21. Eleven patients (69\%) presented early in life with significant cyanosis defined in our hospital as systemic saturation of less than $70 \%$. RVOT stent was used for palliation in nine of them (56\% of our Cohort) and a systemic to pulmonary shunt in the form of modified BT shunt in two patients (Figures 1 and 2). The median age at first palliation was 46 days (range 15-99 days). The median age at total repair for both groups was 6 months (range 3-18 months), the median group for the palliated patients was 6.5 months (range 5-18 months) while the median age for primary repaired patients was 5 months (range 3-11 m). The median weight was $6.9 \mathrm{Kg}$ (range $3.7-8.2 \mathrm{Kg}$ ). Five patients presented with congestive heart failure and needed a medical management before going for a primary repair. The median follows up time was 20.5 months (range 5-130 months).

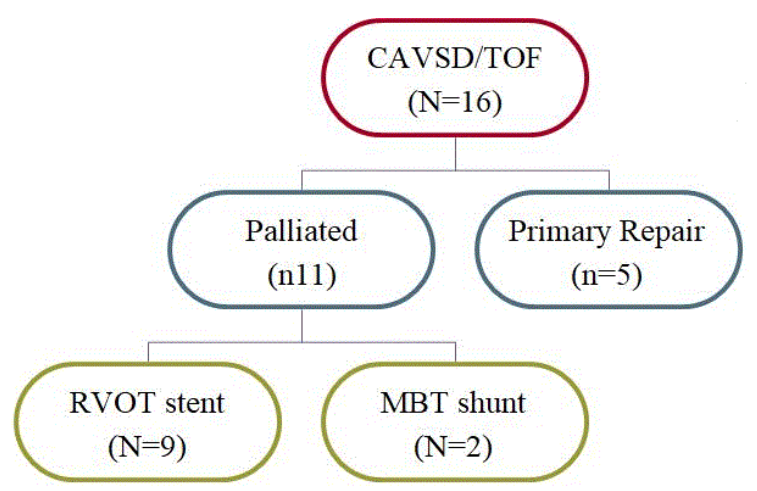

Figure 1: Flow chart demonstrating the number of patients who underwent palliation and primary repair and type of palliation.

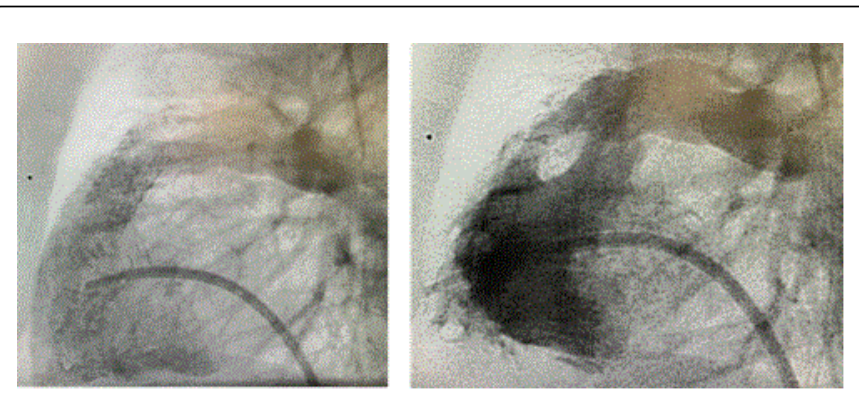

Figure 2: One of four patients with RVOT stenting.

The mean cardiopulmonary bypass time (CPB) was $206.5 \mathrm{~min}$ (range 76-350 $\mathrm{min}$ ), and aortic cross clamp time was $162.5 \mathrm{~min}$ (range 41-201 min). Nevertheless there is no statistically significant correlation between the bypass time and cross clamp time when we compared them to both staged and primary repair groups (Table 1). This is probably due to the small sample size.

\begin{tabular}{|l|l|l|l|l|}
\hline & patients & 2 stage repair Plalliation & Primary repair & P Value \\
\hline Pre-operative & & & & \\
\hline Age months & 6 & 6.5 & 5 & 7.1 \\
\hline Weight (Kg) & 6.9 & 6.8 & 5 & 0.344 \\
\hline Trisomy 21 & 15 & 10 & & 0.188 \\
\hline operative & & & 4 & 0.519 \\
\hline Valve sparing & 5 & 1 & 167.66 & 0.002 \\
\hline Bypass & 197.64 & 205.81 & 116 & 0.436 \\
\hline X clamp & 137.07 & 150.45 & 0 & 0.299 \\
\hline ECMO & 1 & 1 & & 0.519 \\
\hline Length of stay & & & & \\
\hline
\end{tabular}


Citation: $\quad$ Alhawri K, McMahon CJ, Alrih M, Alzein Y, Khan A, et al. (2018) Atrioventricular Septal Defect and Tetralogy of Fallot, a Single Tertiary Center Experience: A Retrospective Review. Med Rep Case Stud 3: 165. doi:10.4172/2572-5130.1000165

Page 3 of 7

\begin{tabular}{|l|l|l|l|l|}
\hline ICU stay (days) & 16.5 & 19.5 & 3.5 & 0.306 \\
\hline Hospital stay (days) & 36 & 44 & 16 & 0.250 \\
\hline Complications & & & & \\
\hline Re operation & & & 0 & 0.221 \\
\hline Early (PPM, PVR+MVR) & 3 & 3 & & 0.519 \\
\hline Late (RVOT stent) & 1 & 1 & $2(25 \%)$ & 0.619 \\
\hline Chylothorax & $8(50 \%)$ & $6(75 \%)$ & 1 & 0.519 \\
\hline Tachyarrhythmia & 1 & 0 & & 0.341 \\
\hline Bradyarrhythmia & 2 & & 2 & 0.639 \\
\hline Sepsis & 5 & 3 & 1 & 0.413 \\
\hline Stroke & 1 & 0 & 0 & 0.341 \\
\hline LAVVR (moderate to severe) & 2 & 2 & 0 & 0.519 \\
\hline Ventricular dysfunction & 1 & 1 & 1 & 0.519 \\
\hline Mortality & 1 (late) & 1 & & \\
\hline
\end{tabular}

Table 1: Comparison between children with and without palliation at final repair.

No early death has occurred after final repair. However, only one late death occurred about three years after final repair from a meningococcal sepsis. Fifty percent of patients $(n=8)$ developed chylothorax. Of whom, only one had pulmonary valve preservation while all the others had a trans-pulmonary patch. Six (75\%) of these patients, who develop chylothorax, were palliated by RVOT stent $(n=5)$ or BT shunt $(\mathrm{n}=1)$. Complete heart block required permanent pacemaker had occurred in two patients $(12.5 \%)$. Both needed a delayed sternal closure due to prolonged bypass time due to difficult exposure. Extra corporeal life support (ECLS) was needed in one of these patients. This patient will be discussed below.

Four patients out of nine (44\%) who underwent palliation before the complete repair needed re-intervention in the form of re-stenting or ballooning of the previous stent before the complete repair. The median time of re-intervention was 2.5 months (range 2-4 months). Only one patient needed early re-intervention after the complete repair. This patient is described in details in the discussion section.

Two patients needed late re-intervention after the complete repair. One patient had RVOT stent due to high RV pressure almost one year after the complete repair. This patient had a Transannular patch with monocusp reconstruction at the time of final repair. The other patient had right and left pulmonary artery stenting eight months post operatively. A year later she went for percutaneous pulmonary valve replacement (Table 2).

\begin{tabular}{|c|c|c|c|c|c|c|c|c|c|c|c|c|}
\hline No. & $\begin{array}{l}\text { Presenting } \\
\text { symptoms }\end{array}$ & $\begin{array}{l}\text { Initial } \\
\text { palliati } \\
\text { on }\end{array}$ & $\begin{array}{l}\text { Age } \\
\text { (day) }\end{array}$ & $\begin{array}{l}\text { Triso } \\
\text { my } 21\end{array}$ & $\begin{array}{l}\text { Total } \\
\text { repair } \\
\text { tech }\end{array}$ & $\begin{array}{l}\text { Age } \\
\text { (Mont } \\
\text { hs) }\end{array}$ & $\begin{array}{l}\text { complicartion } \\
\text { s }\end{array}$ & $\begin{array}{l}\text { Post-operative } \\
\text { echo on last } \\
\text { follow up } \\
\text { (ventricularFun } \\
\text { ction, Lt, Rt } \\
\text { AVVR, RVOT } \\
\text { obstruction, } \\
\text { and pulmonary } \\
\text { regurgitatio) }\end{array}$ & Results & $\begin{array}{l}\text { Follow- } \\
\text { up } \\
\text { MONT } \\
\text { HS }\end{array}$ & $\begin{array}{l}\text { Re- } \\
\text { intervention } \\
\text { post initial } \\
\text { palliation }\end{array}$ & $\begin{array}{l}\mathrm{Re} \\
\text { operation } \\
\text { after total } \\
\text { repair }\end{array}$ \\
\hline 1 & Cyanosis & $\begin{array}{l}\text { RVOT } \\
\text { stent }\end{array}$ & 15 & Yes & $\begin{array}{l}\text { TA, } \\
\text { PATCH, } \\
\text { DSC }\end{array}$ & 6 & $\begin{array}{l}\text { CHB needed } \\
\text { PPM }\end{array}$ & $\begin{array}{l}\text { Good ventricular } \\
\text { function, mild Lt } \\
\text { and Rt AVV reg. }\end{array}$ & $\begin{array}{l}\text { Alive, } \\
\text { well }\end{array}$ & 5 & RVOT Re-stent & \\
\hline 2 & Cyanosis & $\begin{array}{l}\text { RVOT } \\
\text { stent }\end{array}$ & 62 & Yes & $\begin{array}{l}\text { PVp, } \\
\text { PATCH }\end{array}$ & 6 & JET & $\begin{array}{l}\text { - Good bivent. } \\
\text { Function } \\
\text { - Mild RAVVR - } \\
\text { Mild LAVVR } \\
\text { - RVOT PG } 33 \\
\text { mmHg- } \\
\text { moderate PR }\end{array}$ & $\begin{array}{l}\text { Alive, } \\
\text { well }\end{array}$ & 8 & Balloon dilation & \\
\hline
\end{tabular}


Citation: $\quad$ Alhawri K, McMahon CJ, Alrih M, Alzein Y, Khan A, et al. (2018) Atrioventricular Septal Defect and Tetralogy of Fallot, a Single Tertiary Center Experience: A Retrospective Review. Med Rep Case Stud 3: 165. doi:10.4172/2572-5130.1000165

Page 4 of 7

\begin{tabular}{|c|c|c|c|c|c|c|c|c|c|c|c|c|}
\hline 3 & Cyanosis & $\begin{array}{l}\text { RVOT } \\
\text { stent }\end{array}$ & 46 & No & $\begin{array}{l}\mathrm{TA}, 2 \\
\text { patch, } \\
\text { Monocus } \\
\mathrm{p} \\
\text { Contegra, } \\
\text { DSC }\end{array}$ & 8 & $\begin{array}{l}\text { Needed } \\
\text { ECMO } 12 \mathrm{~h} \text { in } \\
\text { ICU, then had } \\
\text { Myectomy for } \\
\text { LVOTO, } \\
\text { pulmonary } \\
\text { Melody valve, } \\
\text { then Melody v. } \\
\text { in LAVV due to } \\
\text { severe Lt } \\
\text { AVVR, } \\
\text { Chylothoraxm } \\
\text { long ICU stay }\end{array}$ & 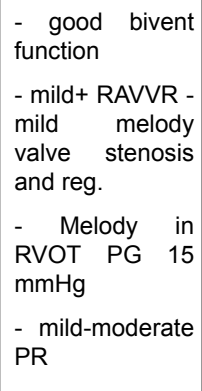 & \begin{tabular}{|l|} 
Alive, \\
mild \\
Mitral \\
Melody \\
valve \\
stenosis \\
and reg., \\
Pulmonar \\
y Meldoy \\
Moderate \\
Regurgita \\
tion
\end{tabular} & 11 & Balloon dilation & PVR, MVR \\
\hline 4 & Cyanosis & $\begin{array}{l}\text { RVOT } \\
\text { stent }\end{array}$ & 46 & Yes & $\begin{array}{l}\text { TA, } \\
\text { Patch, } \\
\text { Monocus } \\
\mathrm{p} \\
\text { Contega, }\end{array}$ & 7 & $\begin{array}{l}\text { Chylothorax, } \\
\text { Long ICU } \\
\text { stay( sepsis) }\end{array}$ & $\begin{array}{l}\text { - good bivent } \\
\text { function } \\
\text { - mild RAVVR - } \\
\text { mild LAVVR } \\
\text { - RVOT PG } 25 \\
\text { mmHg } \\
\text { - Free PR }\end{array}$ & $\begin{array}{l}\text { Alive, } \\
\text { well }\end{array}$ & 12 & Balloon dilation & \\
\hline 5 & & & & Yes & $\begin{array}{l}\text { TA,2 } \\
\text { Patch }\end{array}$ & 13 & & $\begin{array}{l}\text { - good bivent } \\
\text { function } \\
\text { - mild RAVVRV- } \\
\text { mild LAVVR } \\
\text { - RVOT PG } 25 \\
\text { mmHg } \\
\text { - Free PR }\end{array}$ & $\begin{array}{l}\text { Alive, } \\
\text { well }\end{array}$ & 6 & & \\
\hline 6 & Cyanosis & $\begin{array}{l}\text { RVOT } \\
\text { stent }\end{array}$ & 29 & Yes & $\begin{array}{l}\text { TA,2 } \\
\text { Patch, } \\
\text { Divid } \\
\text { Superior } \\
\text { zBridging } \\
\text { Leaflet }\end{array}$ & 11 & Chylothorax & $\begin{array}{l}\text { - good bivent } \\
\text { function } \\
\text { - no RAVVR - } \\
\text { mild LAVVR } \\
\text { - RVOT PG } 22 \\
\text { mmHg } \\
\text { - Free PR }\end{array}$ & alive well & 22 & & \\
\hline 7 & & & & Yes & $\begin{array}{l}\text { TA,2 } \\
\text { Patch, } \\
\text { Monocus } \\
\text { p } \\
\text { Pericardia } \\
\text { I }\end{array}$ & 4 & & $\begin{array}{l}\text { - good bivent } \\
\text { function } \\
\text { - no RAVVR - } \\
\text { mild LAVVR } \\
\text { - RVOT PG } 45 \\
\text { mmHg } \\
\text { - moderate PR }\end{array}$ & $\begin{array}{l}\text { Alive, } \\
\text { well }\end{array}$ & 19 & & \\
\hline 8 & Cyanosis & $\begin{array}{l}\text { RVOT } \\
\text { stent }\end{array}$ & 46 & Yes & $\begin{array}{l}\text { PVp,2 } \\
\text { Patch }\end{array}$ & 8 & & $\begin{array}{l}\text { - good bivent } \\
\text { function } \\
\text { - mild RAVVR - } \\
\text { mild LAVVR } \\
\text { - RVOT PG } 19 \\
\text { mmHg } \\
\text { - Free PR }\end{array}$ & $\begin{array}{l}\begin{array}{l}\text { Alive and } \\
\text { well }\end{array} \\
\text { a }\end{array}$ & 10 & & \\
\hline 9 & Cyanosis & $\begin{array}{l}\text { RVOT } \\
\text { stent }\end{array}$ & 41 & Yes & $\begin{array}{l}\text { TA,2 } \\
\text { Patch, } \\
\text { Monocus } \\
\mathrm{p} \\
\text { Contgra, } \\
\text { Divid } \\
\text { Sup.Bridg } \\
\text { ing } \\
\text { Leaflet }\end{array}$ & 6 & Chylothorax & $\begin{array}{l}\text { - good bivent } \\
\text { function } \\
\text { - mild RAVVR - } \\
\text { mild LAVVR } \\
\text { - RVOT PG } 24 \\
\text { mmHg } \\
\text { - moderate PR }\end{array}$ & \begin{tabular}{|l} 
Alive, \\
needed \\
RVOT \\
stent 1 \\
year later
\end{tabular} & 32 & & RVOT stent \\
\hline 10 & Cyanosis & $\begin{array}{l}\text { RVOT } \\
\text { stent }\end{array}$ & 62 & Yes & $\begin{array}{l}\text { TA,2 } \\
\text { Patch, }\end{array}$ & 5 & Chylothorax & $\begin{array}{l}\text { - good bivent } \\
\text { function }\end{array}$ & $\begin{array}{l}\text { Alive, } \\
\text { well }\end{array}$ & 30 & & \\
\hline
\end{tabular}


Citation: $\quad$ Alhawri K, McMahon CJ, Alrih M, Alzein Y, Khan A, et al. (2018) Atrioventricular Septal Defect and Tetralogy of Fallot, a Single Tertiary Center Experience: A Retrospective Review. Med Rep Case Stud 3: 165. doi:10.4172/2572-5130.1000165

Page 5 of 7

\begin{tabular}{|c|c|c|c|c|c|c|c|c|c|c|c|}
\hline & & & & & $\begin{array}{l}\text { Monocus } \\
\mathrm{p} \\
\text { Perocardi } \\
\text { al }\end{array}$ & & & $\begin{array}{l}\text { - mild RAVVR - } \\
\text { mild LAVVR } \\
\text { - RVOT PG } 16 \\
\text { mmHg } \\
\text { - Free PR }\end{array}$ & & & \\
\hline 11 & & & & Yes & $\begin{array}{l}\text { TA,2 } \\
\text { Patch }\end{array}$ & 5 & \begin{tabular}{lr}
\multicolumn{3}{l}{ Chylothorax, } \\
long & ICU \\
staym, & CHB \\
needed & PPM, \\
(sepsis) &
\end{tabular} & $\begin{array}{l}\text { - good bivent } \\
\text { function } \\
\text { - trivial RAVVR - } \\
\text { mild LAVVR } \\
\text { - RVOT PG } 25 \\
\text { mmHg } \\
\text { - mild PR }\end{array}$ & $\begin{array}{l}\text { Alive, } \\
\text { well }\end{array}$ & 39 & \\
\hline 12 & & & & Yes & $\begin{array}{l}\text { PV p, } 2 \\
\text { Pastch, }\end{array}$ & 5 & & $\begin{array}{l}\text { - good bivent } \\
\text { function } \\
\text { - trivial RAVVR - } \\
\text { mild LAVVR } \\
\text { - RVOT PG } 25 \\
\text { mmHg } \\
\text { - mild PR }\end{array}$ & $\begin{array}{l}\text { Alive, } \\
\text { well }\end{array}$ & 79 & \\
\hline 13 & Cyanosis & $\begin{array}{l}\text { BT } \\
\text { shunt }\end{array}$ & 98 & Yes & $\begin{array}{ll}\text { PVp, } & 2 \\
\text { Patch } & \end{array}$ & 4 & & $\begin{array}{l}\text { - good bivent } \\
\text { function } \\
\text { - mild RAVVR - } \\
\text { mild LAVVR } \\
\text { - RVOT PG } 14 \\
\text { mmHg } \\
\text { - Free PR }\end{array}$ & $\begin{array}{l}\text { Alive, } \\
\text { well }\end{array}$ & 88 & \\
\hline 14 & Cyanosis & $\begin{array}{l}\text { BT } \\
\text { shunt }\end{array}$ & 18 & Yes & $\begin{array}{ll}\text { TA, } & 2 \\
\text { Patch } & \end{array}$ & 16 & Chylothorax & $\begin{array}{l}\text { - good bivent } \\
\text { function } \\
\text { - mild RAVVR - } \\
\text { moderate } \\
\text { LAVVR } \\
\text { - RVOT PG } 15 \\
\text { mmHg } \\
\text { - Free PR }\end{array}$ & $\begin{array}{l}\text { Alive, } \\
\text { well }\end{array}$ & 11 & \\
\hline 15 & & & & Yes & $\begin{array}{l}\text { TA,2 } \\
\text { Patch }\end{array}$ & 18 & & $\begin{array}{l}\text { - good bivent } \\
\text { function } \\
\text { - mild RAVVR - } \\
\text { mild LAVVR } \\
\text { - RVOT PG } 15 \\
\text { mmHg } \\
\text { - Free PR }\end{array}$ & $\begin{array}{l}\text { Died } 3 \\
\text { years } \\
\text { later due } \\
\text { to Sepsis }\end{array}$ & 24 & \\
\hline 16 & & & & Yes & $\begin{array}{l}\text { PVp,2 } \\
\text { Patch }\end{array}$ & 3 & Chylothorax & $\begin{array}{l}\text { - good bivent } \\
\text { function } \\
\text { - trivial RAVVR } \\
\text { - mild LAVVR } \\
\text { - RVOT PG } 25 \\
\text { mmHg } \\
\text { - mild PR }\end{array}$ & $\begin{array}{l}\text { Alive, } \\
\text { well }\end{array}$ & 130 & \\
\hline
\end{tabular}

Table 2: Summary of patient's data. 


\section{Discussion}

Repair of the AVSD/TOF comprises a real challenge for the cardiac surgeon. The repair of TOF often results in pulmonary valve insufficiency or residual stenosis. The resulting volume overload or RV hypertension can potentially worsen right AVV regurgitation and impact significantly on short and long-term outcome. Significant regurgitation of the left AVV can elevate PA pressures and increase pulmonary valve insufficiency, particularly in those following transannular patch reconstruction. These factors, in combination with technical challenges result in a greater risk for repair of CVASD/TOF than the risk for repair of either lesion alone.

The degree of RVOT obstruction determines the time of intervention in these patients. When these patients present early in the neonatal period or in infancy with cyanosis they become a real challenge to the physicians and surgeon. On the other hand, RVOT obstruction protect the pulmonary vasculature and hence allows repair at an older age.

Historical recommendations for age of repair have been in the range of 4-6 years; palliation was performed in severely cyanosed patients to allow them to reach that age $[1,2,7,8]$. However palliation with later repair carries multiple potential complications including prolonged cyanosis, excessive ventricular hypertrophy, volume loading of the ventricle, and onset of progression of atrioventricular valve regurgitation4. Najm et al believe that repair at a younger age is more favorable as demonstrated by faster in hospital recovery and lower incidence of re-operation for an equivalent duration of follow-up. The patients in their cohort presented late, the youngest was 2 months old and an average age of 20 months, range (2-89 months). Our patients presented early with cyanosis median age 46 days (range 15-99 days). We speculate that preliminary RVOT stent followed by total repair may be the procedure of choice.

Staged repair has been recommended because of high mortality rates reported in early series, especially in younger patients $[2,8]$. One reason proposed for delaying the complete repair beyond infancy is the belief that the leaflets of the atrioventricular valve in older patients are thicker and more amenable to repair [9]. Although some reviews with repair of atrioventricular septal defect in early infancy showed no relationship between age at repair and postoperative atrioventricular valve function [10]. The second reason is early presentation with small pulmonary artery size. Barron et al. [11] reviewed the effect of right ventricular outflow tract (RVOT) stenting on subsequent surgical intervention with attention to growth of the pulmonary arteries in patients with isolated tetralogy of Fallot or with associated lesions. The indications for RVOT stenting in their study were firstly, low birth weight patients with tetralogy of Fallot presenting with cyanosis or small pulmonary artery branches; secondly patients with complex anatomy, as AVSD, or comorbidities that increase the risk of primary repair. They also discussed the complications of RVOT stenting including stent migration, failure of deployment, tamponade, need for re intervention, arrhythmias stent endocarditis, coronary artery compression, difficulty of stent removal during final repair and death, yet they concluded that primary RVOT stenting is a valuable and safe mode of staged palliation in TOF in small neonates and children with complex anatomies and significant comorbidities and has only few complication though high incidence of transannular patch use. Four patients out of 13 of their cohort had the diagnosis of CAVSD/TOF. In our cohort four patients required early re-intervention in the form of re-stenting or ballooning of the previous RVOT stent. Two patients needed late re-stenting. One had RVOT stent due to high right ventricular pressure, while the other had branch pulmonary artery stenosis. One year later the patient had pulmonary valve replacement. Apart from one patient who developed junctional ectopic tachycardia which was managed conservatively, no other major morbidity or death. Explanting the stent during the final repair in our series, as in theirs, did not make the placement of the VSD sutures difficult.

There is increasing enthusiasm for single-stage repair for patients with the diagnosis of tetralogy of Fallot only, even in symptomatic neonates-but in most cases, the outcomes are strikingly different from those achieved in older age groups. The Southern Thoracic Society (STS) series analyzed over 3000 TOF repairs (2002-2007) and showed $7.3 \%$ mortality compared with $1.5 \%$ in older infants [11]. The operative mortality and morbidity associated with the surgical BT shunts derived the enthusiasm towards primary repair [12]. These concerns have led to an increasing popularity of primary RVOT stenting as an alternative to the conventional staged approach using systemic-to-pulmonary shunting in such lesions [11].

The decision to send our palliated patients to surgery was made based on close follow up by the cardiologist. Once the patient reached our target age (4-6 months) or target weight (4-6 kg) the cardiologist re-discuss the case in our combined cardiology and cardiac surgery meeting and send the patient for surgery.

Left ventricular obstruction was encountered in only one case in our series. This patient was eleven-month-old with history of neonatal palliative RVOT stenting. He had pre-operative significant common atrioventricular valve regurgitation. The patient was put on extracorporeal life support in the form of extracorporeal membrane oxygenator (ECMO) 12 hours post-operatively due to low cardiac output and vasoplegic syndrome for 5 days. Later, his echocardiography showed significant left ventricular outflow tract obstruction in addition to severe pulmonary insufficiency which was confirmed by a diagnostic catheterization. Myectomy was performed to relieve the obstruction in the left ventricular outflow tract in addition to per-ventricular pulmonary Melody valve replacement. Unfortunately, the patient developed significant mitral regurgitation and we had to replace the mitral valve with bioprosthetic Melody valve inserted surgically. The patient went home after a prolonged hospital stay and is doing fairly well one year after discharge.

Management of the right ventricular outflow tract obstruction follows the same strategies as in patients with isolated tetralogy of Fallot. There is a detrimental effect of incompetent right AVV in the immediate post-operative period as these patients cannot tolerate both incompetent pulmonary valve and right AVV. Monocusp creation is meant to help the patient in the immediate post-operative period although all our series ended up by severe pulmonary regurgitation in the long term. On the long term follow up it seems that severe pulmonary regurgitation is well tolerated by these patients. Excellent results have been demonstrated with both single and double patch techniques for the repair of atrioventricular septal defect [6]. It has been our policy to perform double patch technique to repair the atrioventricular septal defect in all patients whether in isolated defect or if associated with Tetralogy of Fallot.

Chylothorax is a frequent and serious complication associated with congenital heart surgery. It may be caused either by injury of the thoracic duct, increased pressure in the systemic veins exceeding that in the thoracic duct, or a central vein thrombosis [13]. While chylothorax may develop in virtually all types of intrathoracic procedures, several congenital heart operation have been shown to be 
prone to this condition, particularly bidirectional cavopulmonary shunt, Fontan type procedures, tetralogy of Fallot, or AVSD repair [14]. The right ventricular diastolic dysfunction after surgery for repair of tetralogy of Fallot might increase the systemic venous pressure leading to the development of chylothorax [14]. The combination of the two lesions i.e. tetralogy of Fallot and atrioventricular septal defect repair increases the cardiopulmonary bypass time and cross clamp time needed for repair. Biewer et al found that the long duration of cardiopulmonary bypass and cross clamp time are considered significant risk factors for the development of chylothorax in addition to the low birth weight13. In our small cohort the chylothorax occurred in $50 \%(\mathrm{n}=8)$ of patients, and although might not be statistically significant, most of them were of the staged repair. None of our patients had a central venous thrombosis as a cause of chylothorax and all of them were managed conservatively. No one needed surgical intervention.

The mean intensive care and hospital stay are in favor of the primary repair group, 3.5 and 16 days respectively compared to the staged repair cohort 19.5 and 36 days. We have one case with long stay in the intensive care unit due to complicated surgery and need for reintervention. This might explain the long ICU stay in the staged repair group. One should not forget that the primary repair group had more favorable RVOT anatomy while the staged group reflects the more severe and end of the spectrum of this complex disease.

All literature which studies these combined lesions has the limitation of small sample size due to the rarity of this disease. Metaanalysis might be advised.

\section{Conclusion}

CAVSD/TOF can be repaired with low mortality and morbidity. The use of RVOT stent has replaced the surgical (S-P) shunt with acceptable results in our center.

\section{Acknowledgement}

The authors acknowledge the help of pediatric cardiology, cardiothoracic, intensive care, nursing and administrative teams.

\section{Disclosure}

Non-declared.

\section{References}

1. Arcinegas E, Hakimi M, Farooki ZQ, Green EW (1981) Results of total correction of tetralogy of Fallot with complete atrioventricular canal. J Thorac Cardiovasc Surg 81: 768-773.
2. Uretzky G, Puga FJ, Danielson GK, Feldt RH, Juslsrud PR, et al. (1984) Complete atrioventricular canal associated with tetralogy of Fallot: morphologic and surgical consideration. J Thorac Cardiovasc Surg 87: 756-766.

3. Najm HK, Van Arsdell GS, Watzka S, Coles JG, Williams WG, et al. (1998) Primary repair is superior to initial palliation in children with atrioventricular septal defect and tetralogy of Fallot. J Thorac Cardiovasc Surg 116: 905-913.

4. Karl TR (1997) Atrioventricular septal defect with tetralogy of Fallot or double-outlet right ventricle: surgical consideration. Semin Thorac Cardiovasc Surg 9: 26-34.

5. Suzuki K, Katsuhiko T, Kikuchi T, Mimori S (1998) Predisposing factors of valve regurgitation in complete atrioventricular septal defect. J Am Coll Cardiol 32: 1449-1453.

6. McElhinney DB, Reddy VM, Silverman NH, Brook MM, Hanley FL (1998) Atrioventricular septal defect with common valvar orifice and tetralogy of Fallot revisited: Making a case for primary repair in infancy. Cardiology in the Young 8: 455-461.

7. Prifti E, Bonacchi M, Bernabei M, Leacche M, Bartolozzi F, et al. (2004) Repair of complete atrioventricular septal defect with tetralogy of Fallot: our experience and literature review. J cardi Surg 19: 175-183.

8. Pacifico AD, Kirklin JW, Bargeron LM (1980) Repair of complete atrioventricular canal associated with tetralogy of Fallot or double outlet right ventricle: report of 10 patients. Ann Thorac Surg 29: 351-356.

9. Ilbawi M, Cua C, Deleon S, Muster A, Paul M, et al. (1990) Repair of complete atrioventricular septal defect with tetralogy of Fallot. Ann Thorac Surg 50: 407-412.

10. Reddy VM, McElhinney DB, Parry AJ, Brook MM, Hanley FL (1998) Atrioventricular valvar function after primary repair of atrioventricular septal defects by the single patch technique in infancy: when should we repair? J Thorac Cardiovasc Surg 115: 1032-1040.

11. Barrona DJ, Ramchandani B, Muralaa J, Stumper O, De Giovanni JV, et al. (2013) Surgery following primary right ventricular outflow tract stenting for Fallot's tetralogy and variants: rehabilitation of small pulmonary arteries. Europ J Cardio-Thoracic Surg 44: 656-662.

12. Petrucci O, O’Brien SM, Jacobs ML, Jacobs JP, Manning PB, et al. (2011) Risk factors for mortality and morbidity after the neonatal BlalockTaussig shunt procedure. Ann Thorac Surg 92: 642-652.

13. Biewer ES, Zurn C, Arnold R, Glokler M, Schulte-Monting J, et al. (2010) Chylothorax after surgery on congential heart disease in newborns and infants - risk factors and efficacy of MCT-diet. J Cardiothorac Surg 5: 127.

14. Chan SY, Lau W, Wong WH, Cheng LC, Chau AK, et al. (2006) Chylothorax in Children After Congenital Heart Surgery. Ann Thorac Surg 82: 1650-1656. 